\title{
Snow Crab in the Barents Sea: Managing a Non-native Species in Disputed Waters
}

\author{
Tore Henriksen \\ Norwegian Centre for the Law of the Sea, Faculty of Law, UiT The Arctic University of \\ Norway
}

\begin{abstract}
The introduction of a new species to the Barents Sea raises questions as to the rights and duties of states under the law of the sea to exploit, manage and conserve the species. This paper discusses three of them. The first question is whether the snow crab qualifies as a sedentary species. The entitlements and competence of states in respect of living marine resources depend on the location and the characteristics of the species. If it qualifies as a sedentary species under the law of the sea, it is subject to the sovereign rights of the coastal States. Otherwise, it is subject to the sovereign right of the coastal States as well as the freedom of fishing, dependent on its distribution. The second question is what, if any, obligations Norway as a coastal State has in respect of conservation and management of the snow crab and how Norway is complying with these obligations. This includes a discussion of whether the snow crab qualifies as an introduced, alien species and the possible implications for the obligations of the coastal State. The area of distribution of the snow crab includes waters within 200 nautical miles off Svalbard, raising a third question as to the implications of the 1920 Treaty concerning Spitsbergen (Svalbard Treaty) and in particular whether fishing vessels of Contracting parties have the right to participate in the harvest on an equal footing with Norwegian vessels. The Norwegian Snow Crab Regulations effectively reserves the harvest of snow crab for Norwegian fishing vessels. The paper discusses the implications of a recent decision by the Norwegian Supreme Court on dismissal of an appeal by a Latvian vessel and its captain convicted for illegal harvest of snow crab within 200 nautical miles off Svalbard.
\end{abstract}

Keywords: law of the sea, international environmental law, snow crab, alien species, Svalbard and Spitsbergen Treaty

Responsible Editor: Nigel Bankes, Faculty of Law, University of Calgary, Canada

Received: August 2020; Accepted: September 2020; Published: December 2020

\footnotetext{
^Correspondence to: Tore Henriksen, email: jan.solski@uit.no

(C) 2020 Tore Henriksen. This is an Open Access article distributed under the terms of the Creative Commons Attribution-NonCommercial 4.0 International License (https://creativecommons.org/licenses/by-nc/4.0/), allowing third parties to share their work (copy, distribute, transmit) and to adapt it, under the condition that the authors are given credit, that the work is not used for commercial purposes, and that in the event of reuse or distribution, the terms of this license are made clear.

Citation: Tore Henriksen. "Snow Crab in the Barents Sea: Managing a Non-native Species in Disputed Waters" Arctic Review on Law and Politics, Vol. 11, 2020, pp. 108-132. http://dx.doi.org/10.23865/arctic.v11.2545
} 


\section{Introduction}

This paper deals with questions regarding the rights and obligations of coastal States in the conservation and management of a non-native species - the snow crab - in the Barents Sea. More specifically it discusses balancing the right to exploit snow crab as an economic resource with the duty to prevent negative effects of the species on the marine environment. An additional and complicating factor is that other States are challenging the regulatory regime established by Norway and claiming the right under the 1920 Svalbard Treaty to participate in the harvest of the species.

The snow crab (Chionoecetes opilio) is a relatively new arrival to the Barents Sea. It was first observed in $1996 .{ }^{1}$ Its natural habitat includes the northern region of the Pacific Ocean, from the Bering Strait to the waters of British Columbia, and from the northern part of the Sea of Japan to the Korea Strait. ${ }^{2}$ Most of the snow crab stock in the Barents Sea is found on the seabed under the jurisdiction of Russia, but it has gradually migrated into the seabed under Norwegian jurisdiction as far north as the waters east of Svalbard. ${ }^{3}$ Commercial harvest of the species started in 2013. The potential value of the catch in Norwegian waters was estimated around NOK 7.5 billion. ${ }^{4}$ Norwegian and Spanish fishing vessels and subsequently vessels flagged in Russia, Latvia and Lithuania have all started fishing snow crab. ${ }^{5}$ The harvest peaked in 2015 with catches totalling 18,000 tons, down to an estimated 13,000 tons in 2019. ${ }^{6}$-Norway and Russia then agreed that the snow crab is a sedentary species under the United Nations Convention on the Law of the Sea (UNCLOS) and a natural resource of the continental shelf. ${ }^{7}$ Consequently, the two coastal States enjoy sovereign rights to explore and exploit the snow crab on their continental shelves. ${ }^{8}$ In 2010 , the two coastal States had already agreed upon a delimitation of their 200 miles zones and continental shelves in the Barents Sea. ${ }^{9}$ Russia closed access to Norwegian and other States' fishing vessels to its continental shelf in $2017 .^{10}$

Norway adopted regulations restricting the access of fishing vessels to snow crab from 1 January 2015. In effect, the harvest on its continental shelf is reserved for Norwegian-flagged fishing vessels. The harvest of the snow crab has mainly taken place in central parts of the Barents Sea, and within the 200 nautical mile fisheries protection zone around Svalbard. Snow crab prefer temperatures below $4^{\circ} \mathrm{C}$ and mostly live at a depth of 200-300 metres. ${ }^{11}$ Therefore, the projected area of distribution mainly comprises the northern and eastern Barents Sea, e.g. the waters off Svalbard. Snow crab are caught using pots or traps; usually 200-400 chained together 25 metres apart. A vessel may use 12,000 pots. The impact of the snow crab on the ecosystems, habitats and species of the Barents Sea depend on its growth and distribution. ${ }^{12}$ Its main effects are preying on other benthic animals and competing with other species over food. Arctic marine systems are according to Sundet “... simpler than ecosystems further south..." which makes them more vulnerable to external influences such as the introduction of invasive species. ${ }^{13}$ If the pots or traps are not 
regularly tended to or abandoned, they may continue catching snow crab; a practice described as ghost fishing.

In recent years, available information suggests more sober projections for the snow crab harvest. ${ }^{14}$ The total allowable catch for 2020 on the Norwegian continental shelf is set at 4500 tons with a landed value of NOK 400 million. ${ }^{15}$ There are uncertainties as to the sustainability of the harvest as the species is dependent on water temperature and depth, and the availability of food. The warming of the Arctic waters may slow its further migration.

The introduction of a new species to the Barents Sea raises questions as to the rights and duties of states under the Law of the Sea to exploit, manage and conserve the species. This paper discusses three such questions. The first question (section 2) is whether the snow crab qualifies as a sedentary species, or whether it is a species living in the water column. If the former, it is subject to the sovereign rights of the coastal States; and if the latter it is subject to the sovereign rights of the coastal States as well as the freedom of fishing of all states on the high seas, dependent on its distribution between areas within and beyond national jurisdiction. The second question is what international obligations, if any, Norway might have as a coastal State with respect to the snow crab (section 3). This includes a discussion of the obligations that Norway might have if the snow crab qualifies as an introduced, alien species or if it arrived by itself through migration. ${ }^{16}$ The snow crab is shared with Russia, raising questions regarding cooperation obligations. The area of distribution of the snow crab includes waters within 200 nautical miles of Svalbard raising the third question (section 4) concerning the implications of the 1920 Spitsbergen Treaty (Svalbard Treaty), in particular whether the fishing vessels of its contracting parties have the right to participate in the harvest on an equal footing with Norwegian vessels. The paper ends with some conclusions (section 5).

The purpose of discussing these three questions of different character, is to illustrate the complexities of the governance of the marine environment in the Norwegian part of the Arctic. Although the snow crab is a small species, it still has the potential to aggravate disputes regarding the Svalbard maritime zones.

\section{The snow crab: A sedentary species?}

\subsection{General}

When the harvest started, fishing vessels flying predominantly the flags of EU member states exercised the freedom of fishing when they harvested snow crab in an enclave of high seas in the central Barents Sea commonly called the Loophole. In 2015, Norway and Russia agreed to manage the stock as a sedentary species. Its "new" status as a sedentary species meant that the right to explore and exploit the resource (in the Loophole) shifted from a freedom and open access right to an exclusive and sovereign right of the coastal States on whose continental shelf it occurs on the basis of Article 77 of UNCLOS. 
Under UNCLOS a sedentary species is “... organisms which, at the harvestable stage, either are immobile on or under the seabed or are unable to move except in constant physical contact with the seabed or the subsoil", article 77 (4). Critics argue that this definition is not adequately reflective of biological taxonomy, which may lead to disputes over which species qualify. ${ }^{17}$

\subsection{State practice}

Among States the status of the snow crab as a sedentary species seems uncontroversial. Canada manages snow crab on its east coast as a sedentary species. ${ }^{18}$ Furthermore, the EU has accepted that the snow crab is a sedentary species, both on the continental shelf of the Barents Sea as well as on the Canadian continental shelf of the Northwest Atlantic. ${ }^{19}$

The management of the snow crab in the waters under Norwegian jurisdiction was set out in the 2014 Regulations on the Prohibition against Catching of Snow Crab (2014 Snow Crab Regulations), adopted under the Marine Resources Act. ${ }^{20}$ The Regulations include a general ban for Norwegian and foreign-flagged vessels to harvest snow crab on the Norwegian continental shelf, Section 1. Vessels needs a snow crab permit to harvest the species. ${ }^{21} \mathrm{~A}$ special permit is only issued to a vessel licenced under the Act on Participation in Marine Fisheries. ${ }^{22}$ Consequently, foreign-flagged vessels are not granted such permits and may not participate in the snow crab harvest. The implications of this will be addressed in section 4 .

\subsection{The Senator Case}

In a case before the Norwegian Supreme Court sitting as a Grand Chamber (the Senator case) the defendants raised the question of whether the snow crab qualifies as a sedentary species. ${ }^{23}$ The Norwegian Coast Guard boarded the Latvian flagged vessel Senator in January 2017 within the 200 nautical mile Fishing Protection Zone (FPZ) off Svalbard. The inspection revealed that the vessel had set a large number of snow crab traps. As the vessel did not have a Norwegian licence to catch snow crab, the Norwegian Coast Guard escorted it to a port in Norway. The police fined both the captain and the owners for illegal harvest on the Norwegian continental shelf within the 200 nautical mile FPZ. The owner suffered confiscation of the monetary value of the catches. As the captain and the owner did not accept the fines and confiscation, charges of illegal fishing were brought against them before the District Court, which found them guilty of illegal fishing. The Hålogaland Court of Appeal rejected their appeal and concluded inter alia that the snow crab was a sedentary species subject to the sovereign rights of the coastal State. ${ }^{24}$ The defendants appealed the conviction further to the Supreme Court arguing wrongful application of the law by the Court of Appeal. ${ }^{25}$ The appeal concerned both the conclusion that the snow crab was a sedentary species and violation of the equal treatment requirement of the Svalbard Treaty. Section 3 of this paper addresses the latter question. 
One of the main arguments of the defendants before the Supreme Court sitting as a Grand Chamber was that the snow crab is not a sedentary species. The ban on fishing of snow crab under the 2014 Snow Crab Regulations presumes that it is a sedentary species as the ban is applicable to the continental shelf. If the snow crab were not a sedentary species, there would be no legal basis for the criminal charges, and the defendants asked for acquittal. ${ }^{26} \mathrm{~A}$ sedentary species, they argued, requires that the species is immobile. The snow crab was not sedentary as it was able to move over large distances. ${ }^{27}$ The Supreme Court agreed that sedentary species include immobile species but went on to refer to UNCLOS article 77 (4) which added "that is to say". According to the Court this meant that the provision expands on what qualifies as a sedentary species. An immobile species is one type of sedentary species, others include species that move but which are in constant physical contact with the seabed or the subsoil. The decisive criterion was the natural pattern of movement of the snow crab. The Court found it irrelevant that a species is able to move across large areas at the harvestable stage, as long as it is in constant physical contact with the seabed. The Supreme Court, building on the testimony of a marine biologist, was in no doubt that the snow crab qualifies as a sedentary species. ${ }^{28}$

\section{The snow crab and obligations to protect and preserve the marine environment and to conserve marine living resources}

\subsection{General}

The coastal State enjoys sovereign rights on its continental shelf for the purpose of exploring and exploiting its natural resources, including sedentary species, UNCLOS article 77 (1) and (4). Thus, the coastal State may facilitate commercial exploitation of the resource. These sovereign rights seem directed at non-living marine resources, as they do not reference the right or duty to conserve and manage marine living resources, e.g. by regulating access to and exercise of the harvest. However, a right to explore and exploit a sedentary species inherently involves a right to conserve and manage the resource. ${ }^{29}$

UNCLOS does not include a specific obligation for the coastal State to conserve and manage the snow crab, similar to that imposed for the living marine resources of the EEZ. A question to be investigated is whether the coastal State has such obligations, particularly given legal developments in recent years. Of particular concern is that the snow crab is a non-native species of the Barents Sea and its introduction may have negative impact on its ecosystems, habitats and species. Furthermore, under the obligations of UNCLOS and the Convention on Biodiversity $(\mathrm{CBD})^{30}$ to protect the marine environment and conserve marine biodiversity, the coastal State is required to take measures to prevent or control the introduction of new species - described as "alien species" - that may have a negative effect on the environment. Consequently, before discussing possible 
conservation and management obligations (section 3.3), the possible status of the snow crab as an alien or new species under these instruments and its implications must be addressed (section 3.2).

\subsection{The snow crab - obligations with respect to an alien, invasive species UNCLOS and the Convention on Biological Diversity}

The snow crab is clearly a non-native species of the Barents Sea as it originates from the north Pacific (in an area from the Sea of Japan northwards to the Sea of Okhotsk, the Bering Sea and the Beaufort Sea), but is it an alien, invasive species? Under article 196 paragraph 2 of UNCLOS, as part of the obligation to protect and preserve the marine environment, the coastal State shall take "all measures necessary" to prevent, reduce or control the intentional or accidental introduction of new or alien species that may cause significant and harmful changes to the marine environment. A similar obligation follows from article $8(\mathrm{~h})$ of the CBD, applicable to the 200 mile EEZ and the continental shelf: States shall as far as possible and as appropriate prevent the introduction of, control and eradicate alien species that threaten ecosystems, species and habitats. Guidelines adopted by the Conference of the Parties under the CBD specify that this obligation concerns both the intentional and unintentional introduction of alien species. ${ }^{31}$ Consequently, these obligations refer to species which are introduced intentionally or unintentionally by man. As a contracting party to both treaties, Norway is required to comply with these obligations.

There are two hypotheses on how the snow crab arrived in the Barents Sea: The first is that it migrated naturally from the Bering Sea, and the second is that man introduced it accidentally through ballast water. ${ }^{32}$ The latter case would trigger these obligations under the CBD. The 2018 Alien Species List prepared by the Norwegian Biodiversity Information Centre includes the snow crab. ${ }^{33}$ Furthermore, the Norwegian national plan of action for biodiversity identifies the snow crab as a new species in the Barents Sea. ${ }^{34}$ This suggests that the species is considered as a potential alien or invasive species.

Obligations under UNCLOS and the CBD relate to the effects, or more correctly the potential effects, the alien species (snow crab) has on the marine environment and biodiversity. Their thresholds are formulated somewhat differently: "may cause significant and harmful changes" and "threaten the ecosystem, species and habitats" respectively. Neither require actual effects - a threat or a risk is sufficient to trigger the obligations. As referred to above, the impacts of the snow crab on the ecosystems, habitats and species of the Barents Sea depend on the specie's growth and distribution..$^{35}$ Its main effect is to prey on other benthic animals and compete with other species for food. As the Barents Sea ecosystems are simpler than those of other oceans, the effects of the snow crab may be more serious. As the species is relatively new to the Barents Sea, there are uncertainties as regards its sustainability and its effects on the ecosystem. The available information builds partly on data collected under the joint Norwegian-Russian ecosystem cruises, catch data and on 
data from the snow crab stocks on the east coast of Canada and the eastern part of the Bering Sea. The snow crab was included in the 2018 Alien Species List because it was considered a risk to marine biodiversity, and in particular a high risk in the waters off Svalbard. This is due to its large and rapid spread, particularly northwards, and to the uncertainty about its ecological effects. However, the potential preying of cod on snow crab and the possibility that unfavourable higher water temperatures may limit its distribution all add to the uncertainties surrounding its ecosystem effects. ${ }^{36}$

Under both UNCLOS and CBD States are to take "... measures to prevent, reduce and control the introduction of alien species" or to "... prevent the introduction of, control and eradicate alien species...". These are duties of conduct and not of result. Furthermore, the obligations are qualified by the requirement to take the measures "necessary" (UNCLOS) and "as far as possible and as appropriate" (CBD). As described by the Seabed Disputes Chamber of the International Tribunal for the Law of the Sea (ITLOS), this entails a duty "... to deploy adequate means, to exercise best possible efforts, to do the utmost ..." ${ }^{37}$ It is an obligation of due diligence. ${ }^{38}$ Such an obligation entails, in addition to the adoption of appropriate regulations, "... a certain level of vigilance in their enforcement and the exercise of administrative control applicable". ${ }^{39}$ The Seabed Disputes Chamber established that the precautionary approach is an integral part of the due diligence obligation. It is applicable where the "scientific evidence is insufficient", but where there are "plausible indications of potential risk....". ${ }^{40}$ Disregarding such risk would violate the obligation. The obligations under UNCLOS and CBD are applicable where the introduction of new or alien species poses a threat to the marine environment and marine biodiversity. There is no obligation to remove all risk as that may be impossible. ${ }^{41}$ This may well be the case with the snow crab. Since it is spreading over a large area of the Barents Seas, it may be impracticable, unrealistic and even impossible to eradicate the species. The Norwegian Institute of Marine Research (IMR) provides scientific advice to the Ministry of Trade, Industry and Fisheries, including on the management of the snow crab. ${ }^{42}$ IMR notes that the only way to reduce the impact of the snow crab on the marine environment is through extensive harvesting. Consequently, an obligation of due diligence with respect to the snow crab as an invasive alien species entails the monitoring of its spread and impacts, regulating the extent of the harvest/catches to ensure that risks are within acceptable levels as well as ensure that the measures are complied with by vessels licenced to participate in the harvest.

\section{Norwegian regulations}

The Ministry has adopted a plan for the management of the snow crab. ${ }^{43}$ Its main objective is the sustainable harvest of the species, and more specifically a harvest that provides for an economically profitable management of the resource. This is consistent with the objectives of the Marine Resources Act. ${ }^{44}$ Consequently, the snow crab 
is considered a natural resource, to be economically utilised. The objective entails balancing two sub-objectives: maximising the long-term catch yield and minimizing the risk of undesirable ecosystem effects. The latter includes not only the effects of the fishery itself, but also the effects of the snow crab on the ecosystem. Thus, the plan provides for a balance between managing the snow crab as a resource and managing the snow crab as a threat to the ecosystem as a potential alien invasive species. Regarding the first sub-objective, catches are not to exceed the fishing mortality rate that over time produces the maximum sustainable yield (Fmsy) and they shall ensure that the biomass (total weight) of the species are maintained at a level that can support harvest of the maximum sustainable yield (Bmsy). ${ }^{45}$

The second sub-objective may require the adoption of regulations that provide for a more extensive harvest than the first sub-objective. The 2014 Snow Crab Regulations were amended to include measures such as an annual total allowable catch (TAC) and technical measures (closed seasons, minimum sizes of individuals captured and restrictions on bycatch of individuals without fully-grown shells).$^{46}$ Both the TAC and the technical measures are designed to maximise the long-term yield, e.g. not to allow harvest in periods when the species sheds its shell and is particularly vulnerable. None of the measures are specifically designed to address the second sub-objective of the management plan. As noted above, there is still limited knowledge about the effects of the snow crab on the ecosystem other than it has marginal effects on other commercial species and may affect other benthic fauna. Furthermore, these effects depend on whether and to what extent the snow crab will spread across the Barents Sea. The lack of scientific information regarding potential risk to the ecosystem, calls for application of a precautionary approach, which is one of the management principles included in the Marine Resources Act. ${ }^{47}$ The measures taken to achieve the second sub-objective primarily involve collecting more data on the potential impact on the marine ecosystems, which is necessary to assess risk and adequate measures. If the snow crab is an alien invasive species, it is doubtful that Norway, at this stage, is in violation of its obligation of due diligence.

\subsection{A duty to conserve and manage the snow crab if it is not an alien invasive species} Recent scientific reports suggest that the snow crab migrated naturally to the Barents Sea. Genetic studies indicate that there would have been greater genetic similarity between the snow crab of the Barents Sea and the Bering Sea if the species had been introduced through ballast water. ${ }^{48}$ If it is not an alien, invasive species, then the obligations under UNCLOS article 196 paragraph 2 and CBD article 8 (h) are not applicable to Norway. Does this mean that Norway may manage the snow crab as a resource without consideration of negative effects the snow crab may have on the marine ecosystems of the Barents Sea?

Norway's management plan and the measures included in 2014 Snow Crab Regulations document how Norway intends to manage and conserve the snow crab. Does 
Norway have any obligation to take measures to address the effects of these measures on the ecosystem of the Barents Sea?

\section{Obligations under UNCLOS}

While coastal States do not have an explicit obligation under part VI of UNCLOS to conserve and manage the sedentary species of its continental shelf or to minimize the effects of the harvest or of the species on the marine ecosystem, ${ }^{49}$ a coastal State does have obligations with respect to the resources of the EEZ under UNCLOS article 61 . According to Mossop, ${ }^{50}$ this difference has an historical explanation insofar as part VI of UNCLOS is based on the 1958 Continental Shelf Convention. Rothwell and Stephens ${ }^{51}$ in turn explain the absence of any conservation and management obligations for the resources of the continental shelf based on the theory of the continental shelf as a prolongation of the land territory, for which there is no duty to conserve natural resources.

The coastal State is obligated under part XII of UNCLOS to protect and preserve the marine environment, including sedentary species. The obligation to protect and preserve the marine environment includes not only preventing pollution from different sources but also includes the conservation of marine living resources, UNCLOS article $192 . .^{52}$ Recent case law, including the advisory opinion of ITLOS in the Sub-Regional Fisheries Commission case, confirms that conservation of living marine resources is part of protection and preservation of the marine environment. ${ }^{53}$ States have sovereign rights to exploit their natural resources pursuant to their own policies, but consistent with their environmental protection obligations, UNCLOS article 193. The duty to protect and preserve rare and fragile ecosystems and habitats of threatened and depleted species clearly indicates that overall obligation goes further than pollution prevention, article 194 (5)..$^{54}$ The award in the South China Sea Arbitration detailed the obligation to protect and preserve the marine environment, describing it as both a positive and a negative obligation, informed by the "corpus of international law relating to the environment". ${ }^{55}$ The latter may include obligations under CBD. Commenting on the Award, Tanaka ${ }^{56}$ notes that the complex web of treaties relevant to the protection of the marine environment requires a "systematic outlook". The substance of the obligation to protect and preserve the marine environment is not only derived from UNCLOS but is supplemented by other treaty obligations. The Award establishes that the obligation to protect and preserve the marine environment is a duty of due diligence. ${ }^{57}$

Consequently, the coastal State in managing the snow crab as a commercial resource, is required to protect and preserve the marine environment. This obligation obviously relates to the effects of the harvest on the snow crab and on the marine ecosystem, its species and habitats. The snow crab can hardly be described as a threatened or depleted species. The management plan suggests that the snow crab will be harvested sustainably. The scientific evidence available suggests that 
fishing has limited effects on the marine ecosystem and other species. The Norwegian Institute for Marine Research has recommended the use of biodegradable twine in the pots or traps to prevent ghost fishing, a requirement under elaboration. The Fisheries Directorate organizes cruises to remove abandoned fishing gear in Norwegian waters, including pots and traps. ${ }^{58} \mathrm{~A}$ more difficult question is whether the obligation to protect and preserve the marine environment also requires that the coastal State take measures necessary to prevent negative effects of the snow crab on other benthic fauna. The positive obligation to protect and preserve the marine environment, understood as including inter alia rare and fragile ecosystems, suggests that the coastal State is required to take measures to mitigate such effects even if the snow crab does not qualify as an introduced species. As a non-native species, it may affect the existing biodiversity. Furthermore, article 8 (d) and (l) of CBD may provide further specification and supplementation to the obligation of the coastal State. Article 8 operationalises CBD's objective to conserve biological diversity. It entails an obligation to, as far as possible and as appropriate, protect ecosystems, natural habitats and maintain viable populations of species in natural surroundings. Furthermore, States are required to take measures to address significant adverse effect on biological diversity. Applicable to the components of biodiversity in areas under national jurisdiction, these provisions may be read to imply an obligation to take measures regarding non-native species such as the snow crab to prevent negative effects on the benthic fauna in areas. The plan for management of the snow crab responds to such an obligation.

This is an obligation of conduct and of due diligence. Similar to the obligations under UNCLOS article 196 (2) and CBD article 8 (h), it does not require states to eradicate the species but to take adequate measures to reduce its negative effects. In the end, whether the snow crab qualifies as an alien and invasive species may be of little significance.

\subsection{The snow crab as a shared natural resource}

The Snow crab stock of the Barents Sea is a shared natural resource, occurring on both the Norwegian and Russian continental shelves. While UNCLOS article 63(1) imposes an obligation on coastal States to cooperate in the conservation and management of living marine resources shared between their EEZs, there is no similar explicit obligation under UNCLOS with respect to transboundary sedentary species. The two coastal states established the Joint Norwegian-Russian Fisheries Commission in the mid-1970s to comply with their obligation under article $63(1) .{ }^{59}$ The Arctic cod stock is the main fish stock subject to this cooperation. In spite of lack of a specific obligation under UNCLOS, the coastal States do arguably have an obligation to cooperate under general international law. By exercising its sovereign rights to exploit a sedentary species, a coastal State may affect the sovereign rights of the neighbouring coastal State to exploit the same resource. Furthermore, States have 
an obligation under UNCLOS to cooperate on common issues regarding the protection of the marine environment, article 197. A similar duty applies under CBD article 5 .

There is some limited cooperation between Norway and Russia on the snow crab. Snow crab has been on the agenda of the Joint Norwegian-Russian Fisheries Commission since 2015. The Commission has yet to engage actively in the conservation and management of the stock, e.g. by agreeing on a total allowable catch, its allocation and other measures. The two coastal States exchange data through the Commission and express their intention to cooperate on research and on providing reciprocal access to their continental shelf. ${ }^{60}$ Since 2017, Russia has not permitted foreign-flagged vessels to catch snow crab on its continental shelf and has banned Russian-flagged vessels from catching snow crab on the Norwegian continental shelf. However, the annual Norwegian-Russian Ecosystem Survey of the Barents Sea includes investigation of the abundance and distribution of the snow crab. ${ }^{61}$

\section{The snow crab and the Svalbard maritime zones dispute}

\subsection{General}

Fishing vessels mainly harvest snow crab on the continental shelf within 200 nautical miles of Svalbard. This will probably be the situation for years to come. As de facto access to the resource is reserved for Norwegian-flagged fishing vessels, this has led to protests from the EU and its member states. They have demanded access to the harvest for vessels flying the flag of EU member states. The EU argues that vessels flying the flag of member states that are Contracting Parties to the 1920 Svalbard Treaty are entitled to participate on an equal footing in the harvest of snow crab. ${ }^{62}$ The argument is that the non-discriminatory right under article 2 of the Svalbard Treaty to fish and hunt is applicable to the maritime zones generated by the archipelago, including the continental shelf. Norway rejects this claim and argues that it is entitled to exercise its sovereign rights in these zones to the exclusion of vessels flying the flags of other States. The apparent dispute between Norway and the EU over the snow crab adds to several disputes Norway already has had with contracting parties over the geographic scope of the Svalbard Treaty since the mid-1970s, when the 200 nautical mile Fisheries Protection Zone (FPZ) was established. The dispute over the snow crab adds a new layer to this debate as it concerns the continental shelf. The possible applicability of the Svalbard Treaty provisions to the continental shelf has larger implications since, if applicable, it would include equal rights to access the petroleum resources as well as possible restrictions on the taxation scheme of such commercial enterprises under the Svalbard Treaty. This section first offers a general presentation of the dispute over the geographical application of the Svalbard Treaty (4.2) before discussing the specific snow crab dispute (4.3). The purpose is not to establish whether the treaty provisions apply. The paper focuses rather on the 
positions of the parties, how the dispute might be addressed and implications of the dispute.

\subsection{Svalbard maritime zone dispute \\ Duty of non-discrimination}

The contracting parties to the Svalbard Treaty ${ }^{63}$ have recognised the full and absolute sovereignty of Norway over the archipelago of Spitsbergen, article 1. However, Norway is to exercise its sovereignty subject to the stipulations of the Treaty. These stipulations include an obligation of direct and indirect non-discrimination or equal treatment based on nationality, involving the activities specified in articles 2 and 3. These activities include hunting and fishing, access to the archipelago and its waters, engaging in certain types of commercial and industrial activity, and property rights including mineral rights. The duty of equal treatment does not hinder Norway from prohibiting or restricting an activity for reasons other than nationality, such as environmental protection or conservation of resources. Another important and relevant stipulation on the exercise of sovereignty is the restriction on the right to impose taxes, as taxes, dues and duties levied "... shall be devoted exclusively to the said territories ...”, article 8 . Some of the Treaty provisions, such as articles 2 and 3 explicitly apply to the territorial waters of Svalbard. When Norway revised the baselines of Svalbard and extended its territorial waters from 4 to 12 nautical miles in 2004, the rights of the contracting parties to equal treatment were correspondingly expanded. ${ }^{64}$

\section{Duty of non-discrimination beyond the territorial sea?}

As the developments of the Law of the Sea entitled the coastal States to expand their sovereign rights and jurisdiction seawards, there have been questions as to whether the above-mentioned stipulations are applicable in the exercise of sovereign rights and jurisdiction in the maritime zones beyond the territorial waters. In 1977, Norway established a 200 nautical mile Fisheries Protection Zone (FPZ) around the archipelago under its Economic Zone Act. ${ }^{65}$ In order to prevent controversies over any sovereign rights and exclusive rights to living resources, the regulation suspends the ban on foreign-flagged fishing vessels under the Economic Zone Act. ${ }^{66}$ Even though Norway has argued for the right to establish an EEZ and preserve fishing rights for its fishing vessels, Norway has practiced a non-discriminatory regime since 1977. ${ }^{67}$ Contracting parties have challenged this regime frequently, particularly after the arrests of vessels for illegal fishing and punishment of captains and owners. They have argued that the regulations or their enforcement is contrary to the duty of non-discrimination under the Svalbard Treaty. ${ }^{68}$ Some of the cases have ended up before the Norwegian Supreme Court where the defendants have argued for acquittal on the basis that the regulation violated the Svalbard Treaty ${ }^{69}$ To date the Supreme Court has avoided deciding on whether provisions of the Svalbard Treaty 
are applicable to the 200 mile FPZ but has assessed and concluded that the regulations are consistent with the non-discrimination principle. The Court has concluded that allocating quotas between the Contracting parties based on traditional or historic fishing does not qualify as discrimination based on nationality. ${ }^{70}$

The Norwegian Government has reiterated its position on the geographic scope of the Svalbard Treaty in its most recent white paper on Svalbard..$^{71}$ First, it sets out the principles of treaty interpretation, highlighting the wording of the treaty, and underlining that the provisions should be read in context and supported by objective sources that confirm the intentions of the parties. ${ }^{72}$ Consequently, the Svalbard Treaty"... must primarily be interpreted on the basis of the terms and expressions in the actual text". According to the Government, the wording and expressions contained in the Treaty "... clearly indicate the geographical scope of application for the respective provision." ${ }^{73}$ Consequently,

... The special rules stipulated in the Treaty do not apply on the continental shelf or in zones that were created in accordance with provisions in the United Nations Convention on Law of the Sea governing exclusive economic zones. This follows from the wording of the Treaty and is underpinned by the Treaty's prehistory and by its development and system. ${ }^{74}$

Therefore, the provisions of the Svalbard Treaty are not applicable to the maritime zones beyond the 12 nautical mile territorial sea. The Government thus subscribes to an inter-temporal rather than to an evolutionary interpretation of the Svalbard Treaty. ${ }^{75}$ The statement also confirms a shift in position regarding the continental shelf. Previously, the argument had been that Svalbard does not have a continental shelf of its own but that the continental shelf is a prolongation of mainland Norway. ${ }^{76}$ It is now recognised that part of the Norwegian continental shelf is generated by Svalbard. Therefore, the same argument is applicable to the continental shelf as to the 200 nautical mile FPZ: The Svalbard treaty is not applicable beyond the 12 nautical mile territorial sea.

Some contracting parties dispute the Norwegian position and argue that the treaty provisions do apply beyond the territorial sea, whereas others have reserved their positions. ${ }^{77}$ Since establishment of the FPZ, the European Union has communicated to Norway on several occasions that the Svalbard Treaty provides a non-discriminatory right for contracting parties to fish in the zone. ${ }^{78}$

At the centenary for the signing of the Svalbard Treaty 9 February 2020, the Russian Minister of Foreign Affairs Lavrov sent a letter to his Norwegian colleague. ${ }^{79} \mathrm{He}$ described the Svalbard treaty as a "... vital multilateral document that formalised the unique legal status of the archipelago." Furthermore, it “... created the foundation for the cooperation of the concerned states in the interests of development and the use of the Archipelago's vast territory." The main message of the letter was the concern that Norway is not complying with the rights of "equal liberty of access and entry" to Svalbard and the possibility to conduct commercial 
and economic operations there "on a footing of absolute equality." The letter inter alia referenced restrictions on the use of Russian helicopters, the unlawfulness of Norway's fisheries protection zone and the unreasonable extension of nature protection zones where economic operations are limited. The letter did not explain what it meant by "the unlawfulness" of Norway's FPZ. Furthermore, Foreign Minister Lavrov asked for bilateral consultations. The Norwegian Government rejected the request for bilateral talks; arguing that Svalbard is part of Norway and that it is not customary to consult with other countries on how to exercise sovereignty over its own territory. ${ }^{80}$ Norway and Russia seemingly have divergent views on the legal status of Svalbard.

\subsection{The EU-Norwegian snow crab dispute \\ EU issues licences to harvest snow crab}

The EU has communicated to Norway that vessels of contracting parties of the Svalbard Treaty have a non-discriminatory right to participate in the harvest of fish and snow crab in the waters of Svalbard. ${ }^{81}$ Norway has rejected this claim, as its position is that the Svalbard Treaty is not applicable to the continental shelf. ${ }^{82}$ However, Norway has offered the EU snow crab quotas in return for equivalent fishing opportunities for Norwegian-flagged vessels in EU waters. ${ }^{83}$ If accepted, this would mean an acknowledgement of the Norwegian position on the non-applicability of the Svalbard Treaty. Instead, the EU has issued licences to harvest snow crab on the continental shelf off Svalbard and allocated these between member States. ${ }^{84}$ The EU justifies the issuing of licences as a measure "... to ensure that the exploitation is made consistent with such non-discriminatory management rules as may be set out by Norway...". ${ }^{85}$ Norway has argued that this is in violation of the sovereign rights of Norway, as other states may not issue licences to catch snow crab without its consent. ${ }^{86}$ The rationale for issuing the licences is to prevent the EU and its member states from being viewed as acquiescing to the Norwegian position. ${ }^{87}$ When issuing the licences the EU has underlined that member flag States are responsible for ensuring compliance with applicable law. ${ }^{88}$ Consequently, these licences have more of a symbolic value.

\section{A new layer added: Exclusive Right or an obligation of non-discrimination on the Continental shelf}

Norway has applied a different approach to the regulatory regime for the natural resources of the continental shelf than to the natural resources of the 200 nautical mile zone. Here, the pragmatic application of the duty of non-discrimination is replaced with exclusive rights and access for Norwegian-flagged vessels and companies. The reason is obviously that sovereign rights over the natural resources of the continental shelf also include petroleum resources found there. This necessitates a coherent policy. The coastal waters off Svalbard are closed to petroleum activities, 
as they have status as particular valuable and vulnerable marine areas. ${ }^{89}$ However, Norway has announced and issued licenses to explore for petroleum resources on the continental shelf in the northern part of the Barents Sea, of which three blocks are located in areas within 200 nautical miles off Svalbard. ${ }^{90}$ Russia protested arguing that the licence was in violation of the Svalbard Treaty. ${ }^{91}$ As early as 1989 , the UK claimed that the Svalbard Treaty applied to the continental shelf. ${ }^{92}$ The dispute between Norway and the EU over the snow crab, although involving a rather small number of fishing vessels, puts the spotlight on the unresolved dispute on the geographical application of provisions of the Svalbard Treaty, and in particular the continental shelf. Taking a more orthodox position - not applying the pragmatic approach of the 200 mile zone - may lead to an escalation of the dispute.

Latvia is the EU member state most extensively involved in the snow crab harvest before it was closed to the non-coastal States. Latvia and Latvian companies owning fishing vessels previously involved in the harvest have resorted to different types of legal proceedings - internationally as well as nationally - to test the legality of the Norwegian regulation and gain access to the snow crab harvest. Not all of these proceedings deal directly with the geographical scope of the Svalbard Treaty, but instead seek to assess whether Norway has violated economical rights.

\section{Use of international dispute resolution procedures}

First, Latvian and Lithuanian ship-owners filed a complaint with the EFTA Surveillance Authority (ESA) arguing that Norway violated their freedom of establishment under the European Economic Area Agreement (EEA Agreement) by preventing them from establishing a company in Norway which could engage in commercial fishing or the catching of crab. ${ }^{93}$ ESA decided to close the complaint as Norway was competent under the EEA Agreement to exempt snow crab catching from the freedom of establishment. Second, Latvia has petitioned the General Court of the EU to have a letter from the EU Commission setting out its position on the snow crab annulled. ${ }^{94}$ The contested letter was a response to a request by Latvia for the EU Commission to arrange for negotiations with Norway to ensure the rights of EU fishermen to participate in the snow crab fishery, and, if not successful, to initiate international legal proceedings against Norway. Latvia argued that the EU Commission in its reply had failed to act and effectively protect the interests of member states. The EU Commission raised a plea of inadmissibility referring to procedural obstacles to initiating international legal proceedings against Norway: namely that the EU was not competent to bring cases before the ICJ and further that it is not a contracting party to the Svalbard Treaty. Still, the EU has exclusive competence to conserve marine biological resources. The EU Commission also preferred to resolve the dispute through diplomatic and political means. The General Court concluded that the application was inadmissible; the position stated in the letter had no "legally binding nature". ${ }^{95}$ 
A third and pending legal procedure involves an arbitration initiated by Latvian ship-owners with the International Centre for Settlement of Investment Disputes under the Norwegian-Latvian BIT. ${ }^{96}$ The ship-owners argue that Norway has violated its duties to protect Latvian investments by preventing it from engaging in the snow crab catch..$^{97}$ This case stems from the Senator case to be discussed below.

In 2019 Latvia filed a declaration under Article 36 of the ICJ Statute recognising the compulsory jurisdiction of the Court. ${ }^{98}$ This may allow for submission of a dispute on the geographical application of the non-discrimination provisions of the Svalbard treaty to the ICJ, as Norway has long maintained a similar declaration. ${ }^{99}$ The dispute settlement procedures under UNCLOS is not applicable since a dispute between Latvia and Norway would relate to an interpretation and application of the Svalbard Treaty and not to an interpretation or application of UNCLOS. ${ }^{100}$

\section{Dispute resolution through Norwegian Courts}

The Latvian ship-owners also sought a resolution of the dispute through the Norwegian courts of justice/legal system, through the Senator case, referred to above under section 2. Before the Supreme Court sitting as a Grand Chamber, the captain and the ship-owners (defendants) argued a wrongful application of the law by the Court of Appeals. This included violation of the equal treatment requirement of the Svalbard Treaty. The Supreme Court addressed this as a question as to whether the catching of snow crabs was punishable regardless of whether the regulations violated the obligations of Norway under international law (i.e., the Svalbard Treaty). ${ }^{101}$ The formulation of the question meant that the Supreme Court did not need on this occasion to decide on the geographical application of the Svalbard Treaty to the waters beyond 12 nautical miles. However, at the very end of the judgment the Supreme Court could not resist the temptation and stated that the principle of equal rights in any case was not violated. ${ }^{102}$ A Norwegian captain and the ship-owner would also be subject to punishment had they been involved in the unlicensed harvest of snow crab. Consequently, there was no discriminatory treatment based on nationality.

The Court confirmed that Norway is competent under the Svalbard Treaty to manage the natural resources, and that this entails that the contracting parties comply with the measures taken under this competence and that non-compliance is punishable. ${ }^{103}$ The Supreme Court established that the Snow Crab Regulations set up a management system which requires a permit for anyone who wants to catch snow crab. ${ }^{104}$ Unauthorised catching is punishable, regardless of nationality. There is no legal right to a permit as the granting of a permit is a discretionary decision of the authorities. It was established that the captain and the owners had violated the ban on snow crab harvest and that the requirements of guilt were met.

The defendants had argued for acquittal contending that the 2014 Snow Crab Regulations were in violation of the right of equal treatment under the Svalbard Treaty. 
They referred to the international law reservations in both the Marine Resources Act and the Penal Code. The Supreme Court addressed the second question by discussing whether there were legitimate grounds for exempting the defendants from punishment under national and international law. ${ }^{105}$

According to the Supreme Court, under Norwegian law, engaging in an activity without a required permit is punishable and does not lead to acquittal even if the refusal of a permit was invalid due to procedural or other errors. The message is that you cannot act as if a valid permit had been granted. In criminal cases, the courts do not make a preliminary decision on the validity of a refusal to grant a permit. ${ }^{106}$ The correct procedure for an individual or a company that finds that a permit is unfairly denied is to bring a civil action to have the refusal declared invalid. ${ }^{107}$

Then the question before the Supreme Court was whether the result was different because the defendants were foreign nationals. ${ }^{108}$ It concluded that the principle that "... no person can, unpunished, act as if it had a permit is fundamental in a society based on the rule of law ...". ${ }^{109}$ Or, formulated another way, no one may take the law in their own hands but is required to use the procedures prescribed by law to challenge invalid or unlawful acts of the authorities. The Supreme Court concluded that this principle is applicable to areas regulated by international law. Neither the Svalbard Treaty nor international law require that courts in criminal cases make a preliminary judgment as to whether an exemption should be granted if there are alternative ways to effectively review the application of the international legal obligation. ${ }^{110}$ Under Norwegian law, a conflict between an administrative legal rule norm and an international law obligation is resolved through a civil action. If the court concludes that the regulation is invalid, the Norwegian authorities will amend the rule to bring it in accordance with international law. ${ }^{111}$ Consequently, the international law reservation of the relevant legislation did not preclude Norway from punishing foreign nationals for harvesting without a valid permit. ${ }^{112}$ The Grand Chamber of the Supreme Court unanimously dismissed the appeal in a single set of reasons.

What is the significance and consequence of the judgment? First, the Supreme Court of Norway has once again avoided passing judgement on the question of the application of the Svalbard Treaty to the continental shelf (as it has previously with respect to the 200 nautical mile FPZ). The reason may be that the court wants to avoid complicating the position of Norway and that the question is better addressed at the international level through either diplomatic or political channels or through a legally binding decision by an international court or arbitral tribunal.

Secondly, the unanimous judgment from the Grand Chamber of the Supreme Court sends a strong signal to foreign nationals that the strategy they have applied so far is futile. The judgment warns against "taking the law into one's own hands". Harvesting or exploiting natural resources in the 200 mile zone or on the continental shelf off Svalbard without the necessary permits, and, when charged with illegal activities, arguing that the relevant regulations violate the non-discrimination 
principle of the Svalbard Treaty is not a successful strategy. The Court explicitly stated that prosecuting vessels for harvesting without a necessary licence does not qualify as discrimination based on nationality. The approach taken by the Supreme Court will provide guidance in future similar cases. The judgment does, however, offer a procedure for foreign nationals who intend to try the consistency of Norwegian administrative laws such as the 2014 Snow Crab Regulations against the Svalbard Treaty. It requires a foreign national to apply for a dispensation/permit to catch snow crab (even if the Regulations do not allow permits to be granted to foreign nationals). The Marine Resources Act provides the legal basis for the Snow Crab Regulations. As this act includes an international law reservation, the authority deciding on the application has to decide whether to interpret the regulation to include foreign nationals in order to bring it in accordance with the Svalbard Treaty. However, even if there is an equal right to harvest snow crab, there is no guarantee that a foreign national is entitled to a permit. Criteria other than nationality may be applied when deciding on which permits to grant. The foreign national may, similar to a Norwegian national, bring a civil action against the authorities arguing that the refusal is invalid. In the end, in a civil case the Supreme Court may have to decide on the geographical applicability of the Svalbard Treaty and its principle of equal rights.

Another important signal from the judgment is that the Supreme Court has confirmed that Norway is competent to legislate and to enforce with respect to marine natural resources such as the snow crab in the waters and on the continental shelf off the Svalbard archipelago in the northern parts of the Barents Sea and the Arctic Ocean. This is a necessary condition for it to comply with its conservation and environmental protection obligations.

\section{Concluding remarks}

The snow crab case illustrates the complexity of the governance of the marine environment of the Arctic, and, in particular, the waters under Norwegian jurisdiction. First, the fact that some living marine resources are subject to different legal regimes under the law of the sea is clearly noticeable. The snow crab, although a resource shared between Norway and Russia, is not included in the cooperation between the two coastal States on the management of shared fish stocks in the Barents Sea. This bilateral cooperation was a result of the extension of the fisheries jurisdiction of the two States into high seas areas, in compliance with obligations to the international community. Under the Law of the Sea, the continental shelf is a natural prolongation of the land territory. Therefore, the snow crab, as a sedentary species, is regarded as a resource dominated by national interests. The discussions in the Joint NorwegianRussian Fisheries Commission are illustrative of this. The snow crab (as well as the king crab) is one of the items on the agenda of the annual sessions of the Fishery Commission. However, in the case of snow crab this mostly involves mutual 
information and plans for cooperation on research. The Commission is not involved in any joint management or conservation of the snow crab.

UNCLOS is silent on the rights and duties of coastal States to conserve and manage sedentary species. There are historical reasons for this as well as a rationale based on the prolongation of land territory. The developments of international environmental law influencing the law of the sea, as most clearly articulated in the South China Sea Arbitration, imply that sedentary species are included in the duty of States to protect the marine environment and to conserve biodiversity. A major concern is that the snow crab is a non-native species in the Barents Sea with possible negative effects on the fauna of the sea floor, similar to the concern raised by the emergence of the king crab (Paralithodes camtschaticus) in the 1990s. In contrast to the king crab, there is uncertainty as to how the snow crab arrived: Did it arrive through ballast water or did it migrate into the Barents Sea by itself? Recent research indicates the latter. Both UNCLOS and CBD require States to take measures to prevent and control the harmful effects of introduced species on the marine environment and biological diversity. Importantly, even if the species was not introduced, the coastal State still has obligations to prevent negative effects on the ecosystem. The status of the snow crab may therefore not imply a major difference in obligations. The management plan adopted by the Norwegian Government includes minimizing the negative effects of the snow crab on the ecosystem as one of the sub-objectives. This seems to indicate that it is the effects of the snow crab and not the mode of movement into the Barents Sea that is decisive. Management policy has focused on maximising the production of the species and its economic potential. It remains to be seen whether this policy will change as the snow crab spread into the waters off Svalbard and its effects on other benthic fauna become more noticeable.

The snow crab thrives in lower temperatures. Therefore, the projection is that future areas of snow crab distribution will include the northern and eastern parts of the Barents Sea, and consequently the waters off Svalbard. Since the species is not part of the high seas freedom of fishing and Russia has closed its continental shelf to foreign nationals, the Norwegian continental shelf and the potential application of the non-discriminatory principle of the Svalbard Treaty may provide an opportunity for vessels of contracting parties to access the harvest. The question about the applicability of the Svalbard Treaty to maritime zones beyond the 12 nautical mile territorial sea is not new. The arrival of a sedentary species has put the spotlight on the continental shelf. The question of the geographical application of the Svalbard Treaty may attract even more attention in the future as the warming of the oceans lead fish stocks to move northwards. ${ }^{113}$ This may further complicate management of marine resources. Norway has opted for a less pragmatic approach to the continental shelf than the 200 mile FPZ, which may lead to even more confrontations. The 200 mile FPZ was established to maintain a sort of status quo while providing Norway with exclusive competence to regulate the fisheries. This regime, in spite of some controversies seems to have stabilised. The petroleum resources of the continental shelf 
are identified as the reason that the same pragmatic approach has not been applied to the snow crab. It would be hard to argue that an equal right should not apply to petroleum resources. Furthermore, sedentary species are a new phenomenon to these waters calling for an equal treatment regime. Russia is not likely to protest the exclusion by Norway of foreign fishing vessels from harvesting snow crab, as the major part of the snow crab harvest occurs within its continental shelf. Furthermore, bilateral talks through the Joint Norwegian-Russian Fisheries Commission indicate a future possibility for reciprocal access to snow crab for fishing vessels from the two coastal States. The Norwegian snow crab policy mainly affects vessels flying the flag of a few EU members. However, the interests of the EU and these member states in pressuring Norway are not necessarily the same or as strong. This is evidenced by the proceedings before the General Court and discussions in the EU Parliament where the EU Commission seems to have opted for a more conciliatory stance. The relationship between the EU and Norway on fisheries involves more than the snow crab. The EU is probably keen not to jeopardize this relationship. The future will show whether the standoff on the Svalbard Treaty will continue or whether there will be a political or legal resolution to the dispute. The procedure set out by the Supreme Court for challenging the position of the Norwegian Government may require the Norwegian courts of justice to opine on the applicability of provisions of the Svalbard Treaty to the 200 mile zone and the continental shelf. Their findings may not resolve the disputes but may pave the way for international litigation.

\section{NOTES}

1. Ann Merete Hjelset et al., "Snøkrabbe på norsk sokkel i Barentshavet Bestandsvurdering og kvoterådgivning 2020", Havforskningsinstituttet November 2019, available in Norwegian at https://www.hi.no/resources/Snokrabbe-pa-norsk-sokkel-i-Barentshavet-Bestandsvurdering-og-kvoteradgivning-2020.pdf (accessed July 2020).

2. Zalota, A. K., Spiridonov, V. A. \& Vedenin, A. A., "Development of snow crab Chionoecetes opilio (Crustacea: Decapoda: Oregonidae) invasion in the Kara Sea”, 41 Polar Biology, 2018, 1983-1994.

3. ICES, "Barents Sea Ecoregion - Ecosystem overview". In Report of the ICES Advisory Committee, 2019. ICES Advice 2019, Section 5.1, https://doi.org/10.17895/ices.advice.5747 (accessed July 2020).

4. Harald Sakarias Brøvig Hansen, "The Challenging Barents Sea Snow Crab", in Ida Folkestad et al. (eds.), Arctic Governance:Volume 2 Energy, Living Marine Resources and Shipping, I.B Taurus, 2018 162-179 (162).

5. H. S. Brøvig Hansen, (n 4) 163-164.

6. Ann Merete Hjelset et al. (n 1) 6 Table 1.

7. United Nations Convention on the Law of the Sea (Montego Bay 10 December 1982, in force 16 November 1994) 1833 UN Treaty Series, 3; See reference to the agreement in the Minutes of the $45^{\text {th }}$ Session of the Joint Norwegian-Russian Fisheries Commission, item. 10, available in Norwegian at https://www.jointfish.com/content/download/496/6327/file/ 45-norsk.pdf (accessed July 2020).

8. UNCLOS, article 77 . 
9. Treaty between the Kingdom of Norway and the Russian Federation concerning Maritime Delimitation and cooperation in the Barents Sea and the Arctic Ocean (English translation), (Murmansk 15 September 2010, in force 7 July 2011), 2791 UNTS 36.

10. Minutes of the 47 th session of the Joint Norwegian-Russian Fisheries Commission, item 10.2, available in Norwegian at https://www.jointfish.com/content/download/510/6397/ file/47-norsk.pdf (accessed July 2020).

11. J. H. Sundet, "The snow crab - a new and important player in the Barents Sea Ecosystem", Fram Forum 2015, 51-53 (51), available at http://polarenvironment.custompublish.com/thesnow-crab-a-new-and-important-player-in-the-barents-sea-ecosystem.5844740-373134. html\#.Xwl5gHtS9aQ (accessed July 2020).

12. J.H. Sundet, 2015 (n 11), 53.

13. Ibid.

14. Gøril Voldnes, "Klarer vi å gjøre snøkrabben lønnsom?» Norske fiskerier, No. 3 2019, $110-118$.

15. White Paper No. 20 (2019-2020) on Management Plans for Marine Areas under Norwegian Jurisdiction, 70, available in Norwegian at www.regjeringen.no/no/dokumenter/ meld.-st.-20-20192020/id2699370/ (accessed August 2020). General information about the plans in English available at https://www.regjeringen.no/en/topics/climate-and-environment/ biodiversity/innsiktsartikler-naturmangfold/forvaltningsplaner-for-havomrada/id2076485/ (accessed August 2020).

16. Ann-Lisbeth Agnalt et al., "The Snow Crab, Chionoecetes opilio (Decapoda, Majoidea, Oregoniidae) in the Barents Sea", in Bella S. Galil, Paul F. Clark and James T. Carlton (eds.). In the Wrong Place - Alien Marine Crustaceans: Distribution, Biology and Impacts, Springer Dordrecht Heidelberg London New York, 2011 283-300 (294-295).

17. Joanna Mossop, The Continental Shelf Beyond 200 Nautical Miles. Rights and Responsibilities, Oxford University Press, 2016, 64-67.

18. Alexis Bensch et al., Worldwide review of bottom fisheries in the high seas, FAO Fisheries and Aquaculture Technical Paper \#522Rev. 1, 40.

19. European Commission, Director-General for Maritime Affairs and Fisheries Atlantic, Outermost regions and Arctic, Brussels 5 August 2015, Snow Crab Fisheries in the NEAFC Regulatory Area, available at https://www.politico.eu/wp-content/uploads/2017/06/SPOLITICO-17061514340.pdf (accessed July 2020).

20. Regulations of 19 December 2014 No. 1836 on prohibition on catching snow crab; available in Norwegian at https://lovdata.no/dokument/SF/forskrift/2014-12-19-1836?q=sn\%C3\%B8 krabbe (accessed July 2020); Act of 6 June 2008 No. 37 on management of wild-living marine resources (Marine Resources Act), available in an English translation at https://www. fiskeridir.no/English/Fisheries/Regulations/The-marine-resources-act (accessed July 2020).

21. Regulations of 1 October 2006 No. 1157 on special permits to conduct some fisheries and hunting, Section 6, available in Norwegian at https:/lovdata.no/dokument/SF/ forskrift/2006-10-13-1157 (accessed July 2020).

22. Norwegian title: Lov av $26.3 .1999 \mathrm{nr}$. $15 \mathrm{om}$ retten til å delta i fiske og fangst.

23. The Supreme Court of Norway - Judgment of 14 February 2019 ref HR-2019-282-S (Senator case), available in English translation at https:/www.domstol.no/globalassets/upload/ hret/decisions-in-english-translation/hr-2019-282-s.pdf (accessed July 2020).

24. Senator case, paragraph 50.

25. Senator case, paragraph 15.

26. Senator case, paragraph 23.

27. Senator case, paragraphs 50-51.

28. Senator case, paragraph 58.

29. Ibid.; Mossop 2016 (n 17), 96-97. 
30. Convention on Biological Diversity (Rio de Janeiro, 5 June 1992, in force 29 December 1993), 1760 UN Treaty Series, 79.

31. CoP Decision VI/23. Alien species that threaten ecosystems, habitats or species, Guiding Principles for the Prevention, Introduction and Mitigation of Impacts of Alien Species that threaten Ecosystems, Habitats or Species.

32. Ann-Lisbeth Agnalt et al., 2011 (n 16) 294-295.

33. Norwegian Biodiversity Information Centre, Species with increased risk, available at https://www.biodiversity.no/Pages/286686/Species_with_increased_risk\#286692 (accessed July 2020).

34. Meld. St. 14 (2015-2016) Melding til Stortinget (white paper) Natur for livet - Norsk handlingsplan for naturmangfold, 35 .

35. J. H. Sundet, 2015 (n 11), 53.

36. Per Arneberg, Gro van der Meeren, Sylvia Frantzen and Ida Vee (eds.), Status for miljøet $i$ Barentshavet. Rapport fra Overvåkningsgruppen 2020, Rapport fra Havforskningen nr. 3, 2020, 18.

37. Responsibility and Obligations of States Sponsoring Persons and Entities with Respect to Activities in the Area (ITLOS Case No 17), Advisory Opinion, 1 February 2011, para. 110.

38. Ibid. See also Pulp Mills on the River Uruguay (Argentina v. Uruguay), Judgment, I.C.F. Reports 2010, 14 (69 para. 197).

39. Pulp Mills, (n 38) para.197.

40. ITLOS Sea Bed Chamber, Advisory Opinion, 2011 (n 37), para. 131.

41. ITLOS Sea Bed Chamber, Advisory Opinion, 2011 (n 37) para. 116 with reference to International Law Commission Draft Articles on Prevention of Transboundary Harm from Hazardous Activities, with Commentaries, Yearbook of the International Law Commission, 2001, vol. II, 154 (Commentary to Article 3).

42. Advice on quotas: Snow crab on the Norwegian continental shelf in the Barents Sea, available in Norwegian at https:/www.hi.no/hi/radgivning/kvoterad/2020/snokrabbe-pa-norsksokkel-i-barentshavet (accessed July 2020).

43. Plan for management of the snow crab on the Norwegian Continental Shelf, annexed to the Press release on "Changes in regulation of snow crab harvest", dated5 July 2017, available in Norwegian at https://www.regjeringen.no/no/aktuelt/endrer-regulering-av-snokrabbefangst/ id2564252/ (accessed July 2020).

44. Marine Resources Act, Section 1 (n 20).

45. ICES. 2019. Advice basis. In Report of the ICES Advisory Committee, 2019. ICES Advice 2019, section 1.2.https://doi.org/10.17895/ices.advice.5757.

46. Regulations of 19 December 2014 No. 1836 on prohibition on catching snow crab, available in Norwegian at https://lovdata.no/dokument/SF/forskrift/2014-12-19-1836?q=sn\%C3\%B8krabbe (accessed July 2020).

47. Marine Resources Act, Section 7 a).

48. G. Dahle, B. Sainte-Marie, S. H. Hardy, E. Farestveit and A. L. Agnalt, "Snow crab in the Barents Sea - introduction by ballast water or invasion from the East?" (unpublished), referred to in Hjelset et al. Snøkrabbe på norsk sokkel $i$ Barentshavet Bestandsvurdering og kvoterådgivning 2020, IMR, 14.

49. Donald R. Rothwell and Tim Stephens, The International Law of the Sea, $2^{\text {nd }}$ edition, Hart Publishing: Oxford and Portland 2016, 125.

50. Joanna Mossop, 2016 (n 17), 96; Richard Young, "Sedentary Fisheries and the Convention on the Continental Shelf", 55 American fournal of International Law, 1961, 359-373.

51. Rothwell and Stephens, 2016 (n 49), 125-126.

52. James Harrison, Saving the Oceans Through Law: The International Legal Framework for the Protection of the Marine Environment, Oxford University Press, 2017, 170. 
53. Request for Advisory Opinion submitted by the Sub-Regional Fisheries Commission, Advisory Opinion, 2 April 2015, ITLOS Reports 2015, 4 (37, paragraph 120).

54. Chagos Marine Protected Area Arbitration (Mauritius v. United Kingdom), Award, 18 March 2015, RIIA vol XXXI, 359-606 (paras. 320 and 538).

55. The South China Sea Arbitration (Philippines v. Peoples Republic of China), Award, 12 July 2016, paragraph 941, available at https://docs.pca-cpa.org/2016/07/PH-CN-20160712Award.pdf (accessed July 2020).

56. Yoshifumi Tanaka, "The South China Sea arbitration: Environmental obligations under the Law of the Sea Convention", 27 Review of European Comparative E International Law, 2018, 90-96 (92); similarly James Harrison, "The Protection of Species, Ecosystems and Biodiversity under UNCLOS in light of the South China Sea Arbitration: an Emergent Duty of Marine Ecosystem Restoration?" University of Edinburgh School of Law Research Paper Series No 2019/20.

57. The South China Sea Arbitration, (n 55) para. 944.

58. White Paper No. 13 (2019-2020) on Norway's international agreements on fishing for 2020 and the fishing under the 2018 and 2019 agreements, 22, available in Norwegian at https:// www.regjeringen.no/contentassets/6bc67ca7506a4c32be66eb4799f35585/nn-no/pdfs/ stm201920200013000dddpdfs.pdf (accessed July 2020).

59. Irene Dahl, "Maritime Delimitation in the Arctic: Implications for Fisheries Jurisdiction and Cooperation in the Barents Sea", 30 International fournal of Marine and Coastal Law 2015, 120-147 (124-125).

60. Protocol of the 49th session of the Joint Norwegian-Russian Fishery Commission, available in Norwegian at https://www.jointfish.com/content/download/512/6950/file/49-norsk.pdf (accessed July 2020).

61. See IMR-PINRO, https://www.hi.no/hi/nettrapporter/imrpinro? $y=2019 \&$ query $=$ and the report from 2020: https:/www.hi.no/hi/nettrapporter/imrpinro/2020/imr-pinro-1-2020 (both accessed July 2020).

62. See e.g. Council Regulation (EU) 2020/123 of 27 January 2020 fixing for 2020 the fishing opportunities for certain fish stocks and groups of fish stocks, applicable in Union waters and, for Union fishing vessels, in certain non-Union waters, preamble item 49.

63. Treaty concerning the Archipelago of Spitsbergen (Paris 9 February 2020, in force 14 August 1925), 2 League of Nations Treaty Series 8.

64. Act of 27 June 2003 No. 57 relating to Norway's territorial waters and contiguous zone Sections 2 and 5, available at https://www.un.org/Depts/los/doalos_publications/LOSBulletins/bulletinpdf/bulletin54e.pdf; Regulations of 1 June 2001 No. 556 relating to the limit of the Norwegian territorial sea around Svalbard (baselines); The outer limits have been notified consistent with UNCLOS Article 16, https://www.un.org/Depts/los/LEGISLATIONANDTREATIES/PDFFILES/mzn_s/mzn45.pdf (both accessed July 2020).

65. Regulations of 3 June 1977 No. 6 on Fishery Protection Zone off Svalbard, available in Norwegian at https://lovdata.no/dokument/SF/forskrift/1977-06-03-6?q=forskrift $\% 20 \mathrm{om} \% 20$ fiskevernsone (accessed July 2020).

66. Ibid., section 2 .

67. Robin Churchill and Geir Ulfstein, "The Disputed Maritime Zones Around Svalbard" in Myron Nordquist, John Norton Moore and Tomas H. Heidar (eds.) Changes in the Arctic Environment and the Law of the Sea, Brill Nijhoff, 2010, 551-593 (586-587).

68. Ibid., 585-586.

69. See an overview of the Supreme Court cases in Irene Dahl, "Svalbardtraktaten i fiskevernsonen ved Svalbard - Noen utviklingstrekk i Høyesteretts praksis", 57 Lov og Rett 2018, 585-603.

70. The Report of the Supreme Court of 1996 (Rt. 1996) 624ff at 634-636. 
71. Report No. 32 (2015-2016) to the Storting on Svalbard, 19, available at https:// www.regjeringen.no/contentassets/379f96b0ed574503b47765f0a15622ce/en-gb/pdfs/ stm201520160032000engpdfs.pdf (accessed July 2020).

72. Ibid.

73. Ibid., 20

74. Ibid., 20.

75. Robin Churchill and Geir Ulfstein, 2010 (n 67), 585; On evolutionary interpretation, see Pierre-Marie Dupuy, "Evolutionary Interpretation of Treaties: Between Memory and Prophecy" in Enzo Cannizzaro (ed.) The Law of Treaties beyond theVienna Convention, Oxford University Press, 2011, 123-137 (130-131).

76. Churchill and Ulfstein, 2010 (n 67), 564-565 with reference in footnote to Report to the Storthing No. 25 (1973-74) 88; Øystein Jensen, "Defining Seaward Boundaries in a Domestic Context: Norway and the Svalbard Archipelago", 50 Ocean Development $\mathcal{E}$ International Law, 2019, 243-274 (246-247), DOI: 10.1080/00908320.2019.1582669.

77. See references in Churchill and Ulfstein 2010 (n 67), 565 and Erik J. Molenaar, "Fisheries Regulation in the Maritime Zones of Svalbard", 27 The International fournal of Marine and Coastal Law, 2012, 3-58 (17-26).

78. Molenaar, 2012, (n 77) 23-26.

79. See Press release on Foreign Minister Sergey Lavrov's message to Norwegian Foreign Minister Ine Eriksen Soreide on the occasion of the 100th anniversary of the Spitsbergen Treaty; available at https://norway.mid.ru/en/embassy/press-centre/news/press_release_on_foreign_ minister_sergey_lavrov_s_message_to_norwegian_foreign_minister_ine_eriksen_/ (accessed July 2020).

80. Svalbardtraktaten 100 år by Minister of Foreign Affairs Ine M. Søreide and Minister of Justice Monica Mæland, available at https:/www.regjeringen.no/no/aktuelt/traktat_hundre/ id2689324/ (accessed July 2020).

81. Commissioner Vella in European Parliament, Debate 18 January 2018 on EU-Norway dispute on snow crab fisheries in Svalbard, https://www.europarl.europa.eu/doceo/document/ CRE-8-2018-01-18-ITM-011-01_EN.html (accessed July 2020).

82. Report No. 32 (2015-2016) to the Storting on Svalbard (n 71).

83. Feature article by the Minister of Fishery in the daily Dagens Næringsliv 30 January 2017, available at https://www.regjeringen.no/no/aktuelt/avtale_fangst/id2536815/ (accessed July 2020).

84. See Council Regulation (EU) 2020/123 of 27 January 2020 fixing for 2020 the fishing opportunities for certain fish stocks and groups of fish stocks, applicable in Union waters and, for Union fishing vessels, in certain non-Union waters, Annex V.

85. Ibid, preamble paragraph 49 .

86. Press release of the Norwegian Ministry of Trade, Industry and Fishery 30 October 2019 "Must have Norwegian quota to catch snow crab", available in Norwegian at https:// www.regjeringen.no/no/aktuelt/ma-ha-norsk-kvote-for-a-fangste-snokrabbe/id2675907/ (accessed July 2020).

87. See Andreas Østhagen \& Andreas Raspotnik, "Why Is the European Union Challenging Norway over Snow Crab? Svalbard, Special Interests, and Arctic Governance", 50 Ocean Development E International Law, 2019, 190-208 (198).

88. Ibid.

89. White Paper No. 20 (n 15), 28-32.

90. See $23^{\text {rd }}$ licensing round, available at https://www.npd.no/en/facts/production-licences/ licensing-rounds/23rd-round/23rd-licensing-round---announcement/(accessed July 2020). 
91. Barents Observer 5 May 2015, Russia protests drilling in Svalbard zone, available at https:// barentsobserver.com/en/energy/2015/05/russia-protests-drilling-svalbard-zone-05-05 (accessed July 2020).

92. Torbjørn Pedersen, "Security Issues in the Svalbard Area", in Gunhild Hoogensen Giørv, Marc Lanteigne and Horatio Sam-Aggrey (eds.), Routledge Handbook on Arctic Security Routledge, London 2020, 270-282 (278).

93. Closure Decision - Complaint against Norway concerning the prohibition of snow crab catching (College Decision 173/17/COL), available at https:/www.eftasurv.int/cms/sites/ default/files/documents/gopro/3934-Decision \%20-\%20Complaint $\% 20$ against $\% 20$ Norway $\% 20$ concerning $\% 20$ the $\% 20$ prohibition $\% 20$ of $\% 20$ snow $\% 20$ crab $\% 20$ catching.pdf (accessed July 2020).

94. General Court (Fourth Chamber), Order of the General Court of 30 January 30, 2020 Republic of Latvia $v$ Commission (Case T-293/18), 2020 O.J. C95/ 31-32, available at http:// curia.europa.eu/juris/document/document.jsf?text $=\&$ docid $=223004 \&$ pageIndex $=0 \&$ doclang $=\mathrm{EN} \&$ mode $=1 \mathrm{st} \& \operatorname{dir}=\&$ occ $=$ first $\&$ part $=1 \&$ cid $=8327758($ accessed July 2020$)$.

95. Ibid., para. 50.

96. Peteris Pildegovics and SIA North Star v. Kingdom of Norway (ICSID Case No.ARB/20/11), available at https://icsid.worldbank.org/cases/case-database/case-detail?CaseNo=ARB/20/11 (accessed August 2020).

97. Agreement between Norway and Latvia on the mutual promotion and protection of investments, Riga 16 June 1992 in force 1 December 1992.

98. Declarations recognizing the jurisdiction of the Court as compulsory: Latvia, Republic of, https://www.icj-cij.org/en/declarations/lv; Press release of Latvian MFA, “The Foreign Minister signs a declaration on recognizing as compulsory the jurisdiction of the International Court of Justice", https://www.mfa.gov.lv/en/news/latest-news/64147-the-foreign-minister-signs-a-declaration-on-recognizing-as-compulsory-the-jurisdiction-of-the-international-court-of-justice (both accessed July 2020).

99. Declarations recognizing the jurisdiction of the Court as compulsory, Norway, https://www. icj-cij.org/en/declarations/no (accessed July 2020).

100. LOS Convention, Article 279 cf Article 293; Churchill and Ulfstein, 2010, (n 67) 589. See discussions of Valentin Schatz," The Snow Crab Dispute on the Continental Shelf of Svalbard: A Case-Study on Options for the Settlement of International Fisheries Access Disputes”, 22 International Community Law Review, 2020 455-470 (462-465).

101. Senator case, paragraphs 59-60.

102. Senator case, paragraph 83.

103. Senator case, paragraphs $65-66$.

104. Senator case, paragraph 67.

105. Senator case, paragraphs $61-82$.

106. Senator case, paragraph 71 .

107. Ibid.

108. Senator case, paragraph 76.

109. Senator case, paragraph 79.

110. Senator case, paragraph 80.

111. Ibid.

112. Senator case, paragraph 82.

113. M. Meredith et al., "Polar Regions". In H.-O. Pörtner et al. (eds.), IPCC Special Report on the Ocean and Cryosphere in a Changing Climate, The Intergovernmental Panel on Climate Change 2019, 228-229. 